\title{
Nutrient and phytoplankton distribution in the Loire River plume (Bay of Biscay, France) resolved by a new Fine Scale Sampler
}

\author{
Michel Lunven $^{\mathrm{a}, *}$, Jean François Guillaud ${ }^{\mathrm{a}}$, Agnès Youénou $^{\mathrm{a}}$, Marie Pierre Crassous ${ }^{\mathrm{a}}$, Roger Berric ${ }^{\mathrm{b}}$, \\ Erwan Le Gall $^{\mathrm{a}}$, Roger Kérouel ${ }^{\mathrm{a}}$, Claire Labry $^{\mathrm{a}}$ and Alain Aminot $^{\mathrm{a}}$
}

\author{
${ }^{a}$ Ifremer, DYNECO, B.P. 70, 29280 Brest, France \\ ${ }^{b}$ Ifremer, TSI, B.P. 70, 29280 Brest, France \\ *: Corresponding author : mlunven@ifremer.fr
}

\begin{abstract}
:
A new Fine Scale Sampler (FSS) was designed and used in the Loire River plume (Bay of Biscay, France) in order to study phytoplankton distribution in highly stratified water columns. The FSS consists of a linear array of 15 sampling bottles, set horizontally at $20 \mathrm{~cm}$ intervals. Data acquired from the CTD and fluorescence probe of the FSS enable it to be precisely positioned at the depth of the highest density gradient or at the chlorophyll a maximum. The FSS made it possible to investigate fine scale vertical distribution of phytoplankton and relationships with water density, nutrient concentrations or light availability, for spring and summer conditions. Under spring conditions, the entire upper layer exhibited a dominant diatom population (Chaetoceros sociale, Thalassiosira rotula) above 15 meters with evident uptake in dissolved inorganic nutrients and the maximum concentration of dinoflagellates (mainly small forms of Gymnodinium spp. and Gyrodinium spp.) was located 16 meters deep, where light energy began to be a limiting factor for phytoplankton growth. During summer conditions, the maximum phytoplankton biomass $\left(10 \mu \mathrm{g} \mathrm{I}^{-1}\right.$ of chlorophyll a) was only concentrated in the $2 \mathrm{~m}$ thick pycnocline layer, located at a depth of $12 \mathrm{~m}$. The diatom Chaetoceros sociale was dominant in the phytoplankton peak. Dinoflagellates (Dinophysis acuminata and Gymnodinium spp.) were also concentrated around the density gradient. Low inorganic nitrogen concentration $\left(<0.2 \mu\right.$ mol..$\left.^{-1}\right)$ was responsible for the limitation of phytoplankton production in the surface layer above the pycnocline, and the phytoplankton growth was irradiance-limited underneath the pycnocline.
\end{abstract}

Keywords: Phytoplankton, nutrients, thin layer, sampling, density discontinuity, plankton patchiness. 


\section{Introduction}

In coastal ecosystem studies, distribution of phytoplankton biomass and assemblage is often documented with respect to physical and chemical structures like gradients of salinity or nutrients. An important goal is to characterize the spatial variability of coastal ocean which can be horizontally or vertically found. Patchiness has been defined by Mackas et al. (1985) as variability of plankton biomass and composition at horizontal scales $(10 \mathrm{~m}-100 \mathrm{~km})$ and at vertical scales $(0.1-50 \mathrm{~m})$. During field operations, these heterogeneities are accurately identified and estimated by scan-fish techniques (Benfield et al., 1996) or autonomous underwater vehicles (Yu et al., 2002) but because of sampling limitations, the precise description of the biological patchiness is often difficult to obtain. Nevertheless, in order to identify the main characteristics of primary production in coastal waters, the relationship between horizontal and vertical phytoplankton distribution and water column characteristics must be clarified. This requires accurate investigation and characterization of the physiochemical and physical environment.

Vertical fine phytoplankton structures found in coastal areas highly depend on the availability of light, salinity, temperature and nutrient vertical gradients. Numerous studies in recent years have shown the existence of thin chemical and biological layers controlled by hydrological and physical forcing (Cowles and Desiderio, 1993; Dekshenieks et al., 2001). Moreover, the species growing in those layers can sometimes be responsible for toxic events (Gentien et al., 1995).

Since 2001, IFREMER has led a multi-disciplinary research program in the Bay of Biscay (France) in order to understand interactions between fisheries resources, the marine environment and human pressure at a regional scale. The goal of this program is to analyze, understand and forecast the system's development depending on various climatic and economic scenarios. The northern part of this Bay is characterized by its broad continental shelf and significant fresh water discharge from the Loire River. This input induces strong physical forcing which greatly influences phytoplankton production and consequently, higher trophic levels.

During various oceanographic cruises carried out over the Bay of Biscay, vertical thermohaline stratifications were easily identified using a custom pelagic profiler. Real-time data acquisition made possible by this profiler was very useful in determining the optimal depth for water samples for chemical and biological analyses. However, the comparison of discrete bottle salinity values with in situ measurements highlighted significant differences in highly stratified waters. This can be explained by the equipment's design. First, the sensors are located at the base of the sampling bottles which are arranged vertically (bottle's length: $0.9 \mathrm{~m}$ ). Secondly, hydrodynamic disturbances are caused by the movements of the pelagic profiler which stirs up the water column, due to the ship's motions. Consequently, vertical gradients tend to be mixed and smoothed with conventional sampling techniques. This results in misestimating dissolved nutrients, the true abundance of living organisms such as phytoplankton cells and of a mix of algal cells or zooplankton which may be naturally separated in thin layers (Alldredge et al., 2002; Rines et al., 2002). In such stratified waters, representative samples for biological or chemical analyses can only be obtained by using specific systems, sampling water at short intervals without disturbing thin vertical structures. These difficulties, which have limited fine scale sampling, have been widely reported in the literature by numerous authors who have developed custom techniques to improve sampling reliability in vertical gradients (Owen, 1989; Bjørnsen and Nielsen, 1991; Donaghay et al., 1992; Maar et al., 2003).

A new Fine Scale Sampler (FSS) was developed at IFREMER in order to study the finescale distribution of nutrients and plankton species in relation to hydrological and physical conditions. This paper presents this new system which has been deployed since 2002 in the north of the Bay of Biscay to study spring and summer conditions in the Loire plume. Preliminary results have highlighted the interest of the method, showing that fine scale sampling over representative stations, can determine the precise vertical distribution of nutrients and phytoplankton assemblage variability, and thus provide relevant information about phytoplankton behavior and dynamics with respect to the physiochemical structures of the water column. 


\section{Material and methods}

The FSS (Figure 1) is derived from the MPS (Micro Patch Sampler) designed by Owen (1989) and from the HRS (High Resolution Sampler) developed by Bjørnsen and Nielsen in 1991. It is made up of a structure equipped with fifteen 2 liter sampling bottles vertically spaced $20 \mathrm{~cm}$ apart.

The main advantage of the FSS compared to the MPS and HRS consists in a built-in CTD (Conductivity, Temperature, Depth) probe (SBE 19 plus, Sea Bird Electronics, Washington, USA), with a fluorescence sensor (SEAPOINT) and a PAR sensor (LICOR) for irradiance measurement. During deployment, measurements from the sensors enable an accurate positioning in the water column. Operated in real time by a custom software, the FSS is lowered through the water column and then winched up to the targeted depth, selected according to the data acquired and transmitted by the CTD, fluorescence and PAR sensors. The structure is equipped with a large fin mounted on the rear of the metal frame. During sampling, to minimize vertical mixing by the FSS, the ship moves very slowly forward (around 0.5 knot), in order to maintain a smooth flow inside the bottles without vertical disturbance of the medium. The 15 bottles are closed simultaneously from the deck by activating an electromagnet which pulls up a central metal rod releasing the mechanism of bottles closure. In this way, sampling is synchronized with the available sensor data, contrary to the MPS and the HRS, whose bottle closure is operated using a messenger dropped down along the hydro-wire.

We chose to place the sampling bottles in front of the sampler in order to optimise the quality of the sampling. The CTD probe was disposed behind the bottles. Because of this design, sensor data could be slightly biased when describing fine structure. However, since the ship moves forward slowly, we expect that the water is renewed correctly in the 15 bottles. Using the same technique, Owen (1989) demonstrated that discrete layers are sampled distinctly and are only disturbed in the wake of the instrument. It should also be considered that an optimal use of the FSS can be obtained under light wind conditions, which favor the establishment of vertical gradients. Since the ship moves less under these conditions, this also allows optimal positioning of the instrument at the chosen sampling depth.

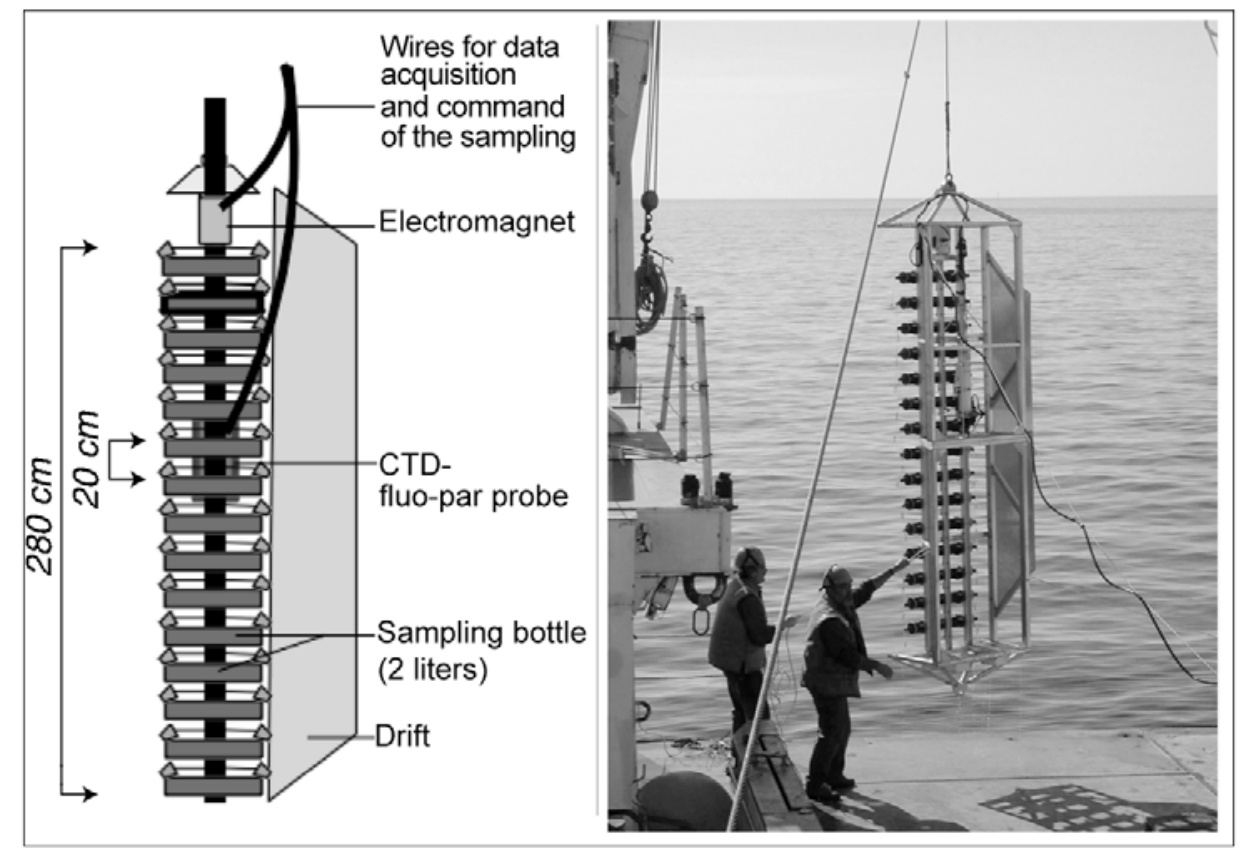

Figure 1: Side view and photograph of the Fine Scale Sampler. 
As mentioned above, Fine Scale Sampling is a complementary method to conventional profiling by our pelagic profiler which in its complete configuration integrates a CILAS particle size analyzer (Compagnie Industrielle des Lasers, Orleans, FRANCE), a SBE25 CTD probe (Sea-Bird Electronics, Washington, USA), a video-system (Lunven et al., 2003) and a SBE 32 carrousel water sampler (Sea-Bird Electronics, Washington, USA). During field operations, this profiler acquires in real time depth, temperature, salinity, chlorophyll-like fluorescence, optical back-scattering and photosynthetically available radiation (PAR). Based on diffraction pattern analysis, the particle size analyzer (PSA) measures the total volume of particles in an 8-ml free flow cell and their size distribution over 30 classes from 0.7 to $400 \mu \mathrm{m}$ (for a complete description, see Gentien et al., 1995). Vertical distribution of particle by size can be synthetically presented by averaging the particle distributions by bins of 1 meter. The diffraction method enables the quantification of typical particle populations: sedimentary particles, phytoplankton, aggregates... During profiles, water sampling is performed using the SBE32 water sampler in the specific layers revealed by the sensors. If highly stratified layers are detected (pycnocline, phytoplankton thin layers...), the FSS is immediately deployed on the same station, in order to obtain high resolution sampling within the vertical gradient. The two sets of water samples from both profilers are then pooled and treated following the same analytical method, giving an accurate description of the vertical distribution of the studied parameters.

After retrieval of the profilers, water samples from each bottle are immediately well mixed and then aliquoted for biological or chemical analyses. Samples for chlorophyll $a$ analyses are filtered using $47 \mathrm{~mm}$ GF/F filters and determined following the fluorometric analysis method of Strickland and Parson (1972). Samples for nutrient measurement $\left(\mathrm{NO}_{3}, \mathrm{NO}_{2}, \mathrm{NH}_{4}, \mathrm{PO}_{4}\right)$ were filtered in-line through a Gelman $10 \mu \mathrm{m}$ polypropylene membrane and quickly frozen $\left(-20^{\circ} \mathrm{C}\right)$. For silicate, the water was filtered through $0.8 \mu \mathrm{m}$ cellulose nitrate membranes, using an all-plastic device, and preserved by adding mercuric chloride $\left(20 \mathrm{mg} \mathrm{l}^{-1}\right)$. Analyses were performed in the onshore laboratory using a Technicon Autoanalyzer. For $\mathrm{NO}_{3}, \mathrm{PO}_{4}$ and $\mathrm{Si}(\mathrm{OH})_{4}$, manual methods of Strickland and Parsons (1972) were adapted following Grasshoff et al. (1983). $\mathrm{NH}_{4}$ was measured according to Kerouel and Aminot (1997). Phytoplankton samples for species counts were preserved in a lugol-glutaraldehyde solution (1\%). The abundance of microplankton was determined by settling 10 or $50 \mathrm{ml}$ of water from each sample for $48 \mathrm{~h}$ in sedimentation chambers. Counts were made using an inverted microscope (Leitz Fluovert).

A quantitative estimation of in situ chlorophyll $a$ was performed by computing the relationship between in situ fluorescence and laboratory chlorophyll $a$ values. For both seasonal situations, the calculated relationship (Table I) was applied to all fluorometer data.

The FSS equipment was deployed at two stations in the Bay of Biscay during the GASPROD cruise (spring conditions, April 2002) and during the VILOIR cruise (early summer conditions, June 2003). The two sampling stations are not far apart (3 miles) and are located around 20 nautical miles west of the Loire's mouth (Figure 2). 


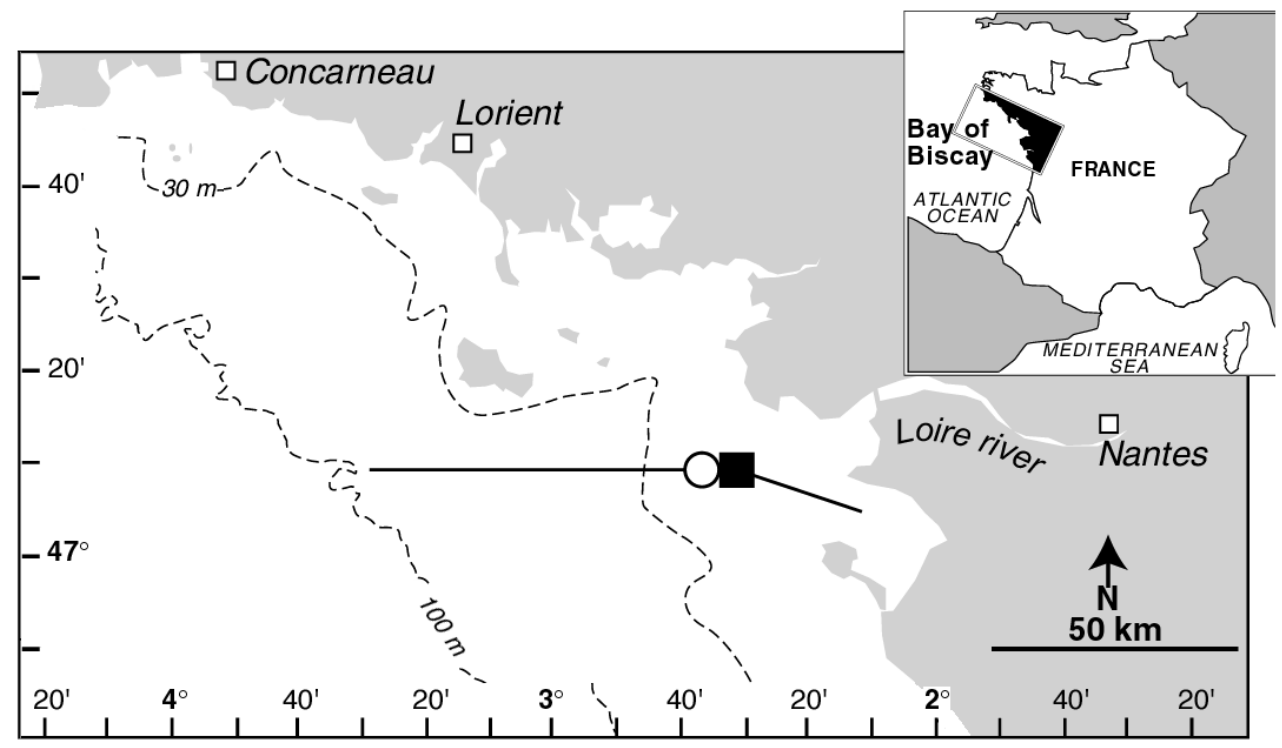

Figure 2: The 2 stations sampled with the FSS, on 14 April 2002 (GASPROD cruise, open circle) and on 21 June 2003 (VILOIR cruise, black square); the transect shown in Figure 3 is indicated on the map.

Table 1: Relationship between in situ fluorescence and laboratory chlorophyll a values

\begin{tabular}{lll}
\hline Situation & Relationship & $\mathrm{R}^{2}$ \\
\hline Spring & Chlo a $=(1.19 \times$ Fluo $)-0.95$ & 0.73 \\
\hline Summer & Chlo a $=(1.12 \times$ Fluo $)-0.46$ & 0.69 \\
\hline
\end{tabular}




\section{Results}

\subsection{Physiochemical conditions in the river plume}

\subsubsection{Spring conditions}

Deploying the classic pelagic profiler provided a spatial description of the physiochemical parameters in the river plume. At that period, temperature values did not exceed $11.5^{\circ} \mathrm{C}$ and exhibited weak horizontal and vertical gradients along the transect (Figure 3). Salinity distribution revealed a large extension of the Loire plume with regard to the high river flow. Fluorescence distribution showed that high chlorophyll $a$ concentrations $\left(2.5-5 \mu \mathrm{g} \mathrm{l}^{-1}\right)$ were located offshore, all over the euphotic layer. The strongest vertical gradients in both chlorophyll $a$ and salinity were observed on 14 April 2002 at station 30. At this station, measurements from the in situ Particle Size Analyzer revealed a large amount of large particles in the surface layer, above 15 meters (Figure 4). In order to sample the vertical gradient detected around 16 meters, the FSS was immediately deployed at this station. The wind speed ranged from 0.5 to $3 \mathrm{~m} \mathrm{~s}^{-1}$, allowing optimal conditions for fine scale sampling.

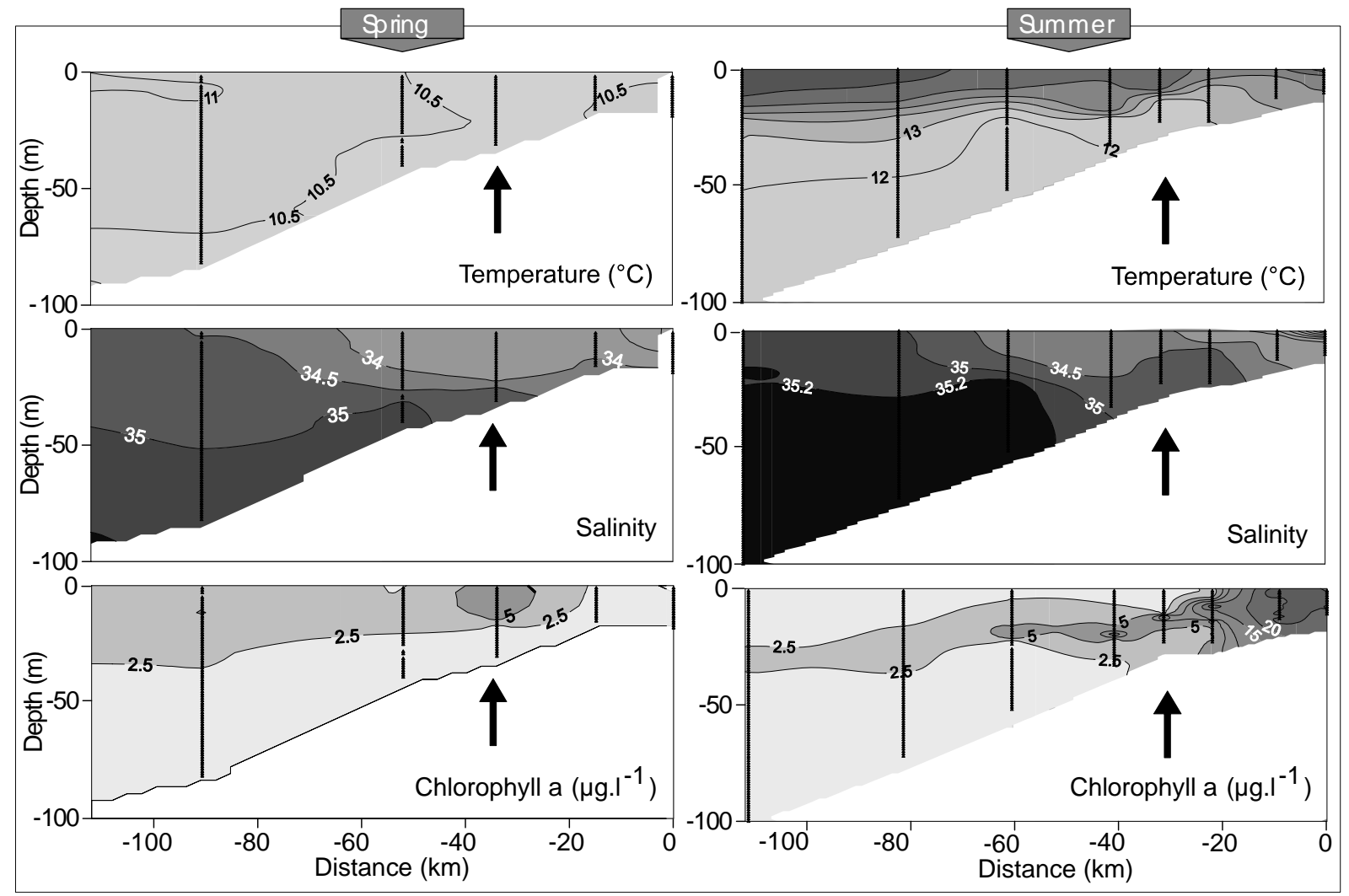

Figure 3: Vertical distribution of temperature, salinity, and chlorophyll $a$ measured by the classic pelagic profiler along a transect off the Loire estuary (located in Figure 2) in spring (left) and summer (right). The vertical arrows indicate the stations where the Fine Scale Sampler was deployed. 


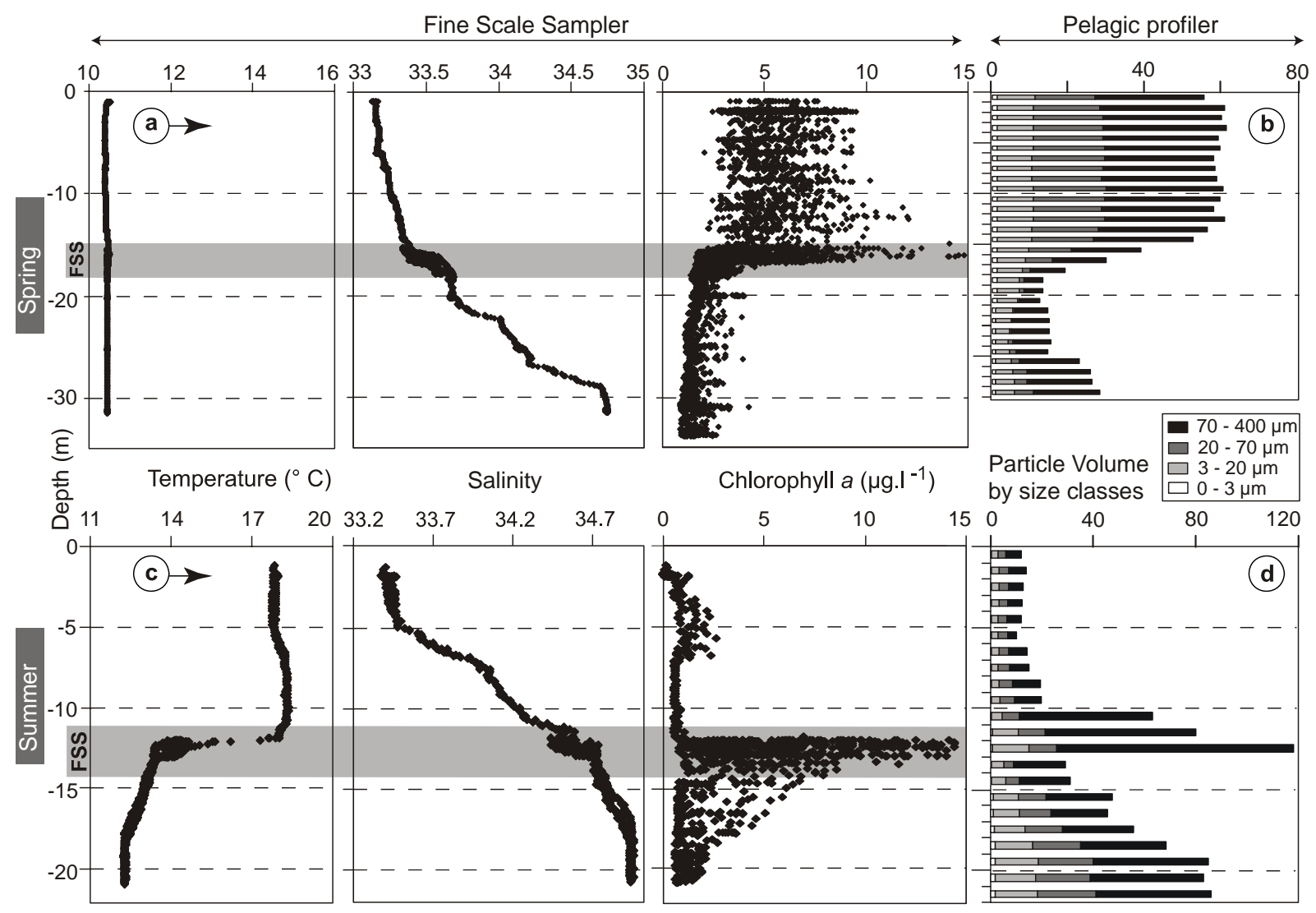

Figure 4: Vertical profiles of (a) temperature, salinity and chlorophyll $a$ like fluorescence from the FSS and (b) Particle Volume by size classes (as measured by the Particle Size Analyzer fitted on the pelagic profiler: particle size distributions averaged by steps of 1 meter ) at station 30 (14 April 2002 - sensors data). (c) and (d) represents the same graphs for the summer situation (21 June 2003, station 23). The grayed area over the FSS profiles indicates the position of the device at the sampling time.

\subsubsection{Summer conditions}

The physiochemical conditions observed on the 19 to 26 June 2003 cruise were typical for summer, i.e., decreasing extent of the Loire plume and presence of a strong thermocline in the water column (Figure 3). Contrary to spring conditions, where the phytoplankton biomass was mainly located offshore in the surface layer, the summer conditions showed enhanced chlorophyll $a$ concentration in the coastal waters. Horizontal and vertical distributions of chlorophyll exhibited two distinct maxima. One was located in the mouth of the Loire River where the chlorophyll $a$ was homogeneously distributed in the water column; the second was measured in the stratified area off the estuary, reaching $10 \mu \mathrm{g} \mathrm{l}^{-1}$ at a depth of around 12 meters at station 23, above the cold and salty oceanic waters. In contrast with spring, the in situ Particle Size Analyzer measurements indicated low particle quantities in the upper layer and the presence of a large number of particles around 12 meters, with large particles $(70-400 \mu \mathrm{m})$ predominating (Figure 4). Original results from the PSA showed that the particle size measurements were heterogeneously distributed around the pycnocline suggesting a high patchiness in particle populations and quantities (data not shown).

To investigate the chlorophyll $a$ maximum around 12 meters, the Fine Scale Sampler was deployed on 21 June 2003 at station 23. The wind speed ranged from 2 to $5 \mathrm{~m} \mathrm{~s}^{-1}$, offering good weather conditions for fine scale sampling. 


\subsection{Fine scale sampling in the Loire River plume}

\subsubsection{Spring period}

At station 30, the preliminary profile made using the FSS showed lower salinity in the upper layer and the presence of a halocline at $16 \mathrm{~m}$ (Figure 4). At this depth, a sharp decrease in chlorophyll marked the bottom of the homogeneous surface layer. No significant thermal gradient could be observed in the water column $\left(\mathrm{t}=10.40-10.45^{\circ} \mathrm{C}\right)$.

The FSS was therefore positioned and operated in the halocline at $16.2 \mathrm{~m}$ in depth (the highest bottle at $15 \mathrm{~m}$, the lowest one being at $17.8 \mathrm{~m}$ ). The results firstly show a marked decrease in chlorophyll $a$ (from 5 to $1.5 \mu \mathrm{g} \mathrm{l}^{-1}$ ), just below the halocline. The sudden increase in the pheopigment content under the cline revealed a shift in the phytoplankton condition in the bottom water (Figure 5). The actual available light intensity fell below $1 \%$ of surface solar irradiance at the $16 \mathrm{~m}$ depth, corresponding to the limit of the euphotic depth.

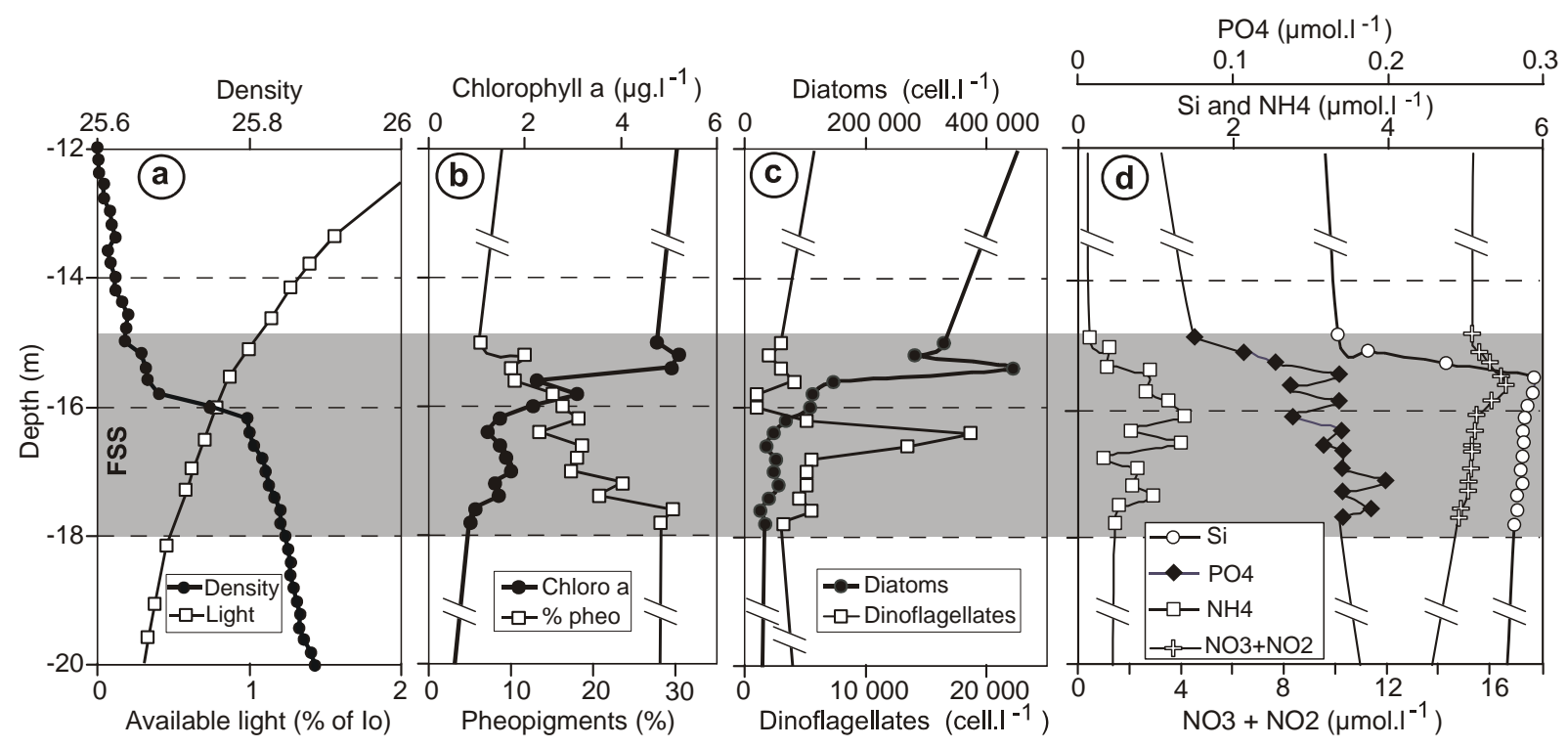

Figure 5: Vertical profiles of (a) density and available light, (b) Chlorophyll $a$ and pheopigment, (c) Diatoms and Dinoflagellates, (d) Dissolved nutrients ( $\mathrm{Si}, \mathrm{PO}_{4}, \mathrm{NH}_{4}, \mathrm{NO}_{3}+\mathrm{NO}_{2}$ ) around the density gradient ((a): sensors data; (b) (c) (d): chemical and biological analyses on the samples obtained by the FSS).

In the surface layer, the dominant species were Chaetoceros sociale and Thalassiosira rotula, i.e. diatoms typically found in spring blooms in this region. There was a clear change in the phytoplankton assemblage with an increase in dinoflagellate density under the halocline. Moreover, it could be seen that the high dinoflagellate growth (with a dominance of small species of Gyrodinium spp. and Gymnodinium spp.) was concentrated in a half-meter thin layer, just below the diatom maximum (Figure 5).

The vertical distribution of nutrients highlights the uptake of inorganic nitrogen, silicate and phosphate in the surface layer, due to diatom development (Figure 5). The lowest phosphate concentration is observed at the top of the water column $\left(0.05 \mu \mathrm{mol} . \mathrm{l}^{-1}\right)$, assumed to be a limiting level for phytoplankton growth (Labry et al., 2005; Sarthou et al., 2005). Below $15 \mathrm{~m}$ depth, nutrients became available but light became the limiting factor $(<1 \%$ Io) for diatom development. The highest ammonium concentration was encountered within the halocline $\left(1.28 \mu \mathrm{mol} . \mathrm{l}^{-1}\right.$ at $\left.16.2 \mathrm{~m}\right)$. This maximum can be attributed to mineralization of organic nitrogen accumulated in the pycnocline, and can enhance dinoflagellate growth (Le Corre et al., 1993). 
Thanks to the FSS data at station 30, nutrient depletion was obvious from comparison of measured concentrations with reference values expected from conservative mixing. The Loire mouth stations enabled to determine the conservative dilution scheme (Figure 6), thus difference between reference and measured values was attributed to consumption by phytoplankton. Calculated nutrient uptake ratios $(\mathrm{N} / \mathrm{P}=16.8$ and $\mathrm{Si} / \mathrm{N}=1.2)$ were similar to usual values and represent nutrient consumption by prevailing diatoms in the surface layer (Redfield et al., 1963; Brzezinski, 1985; Flynn and Martin-Jézéquel, 2000).
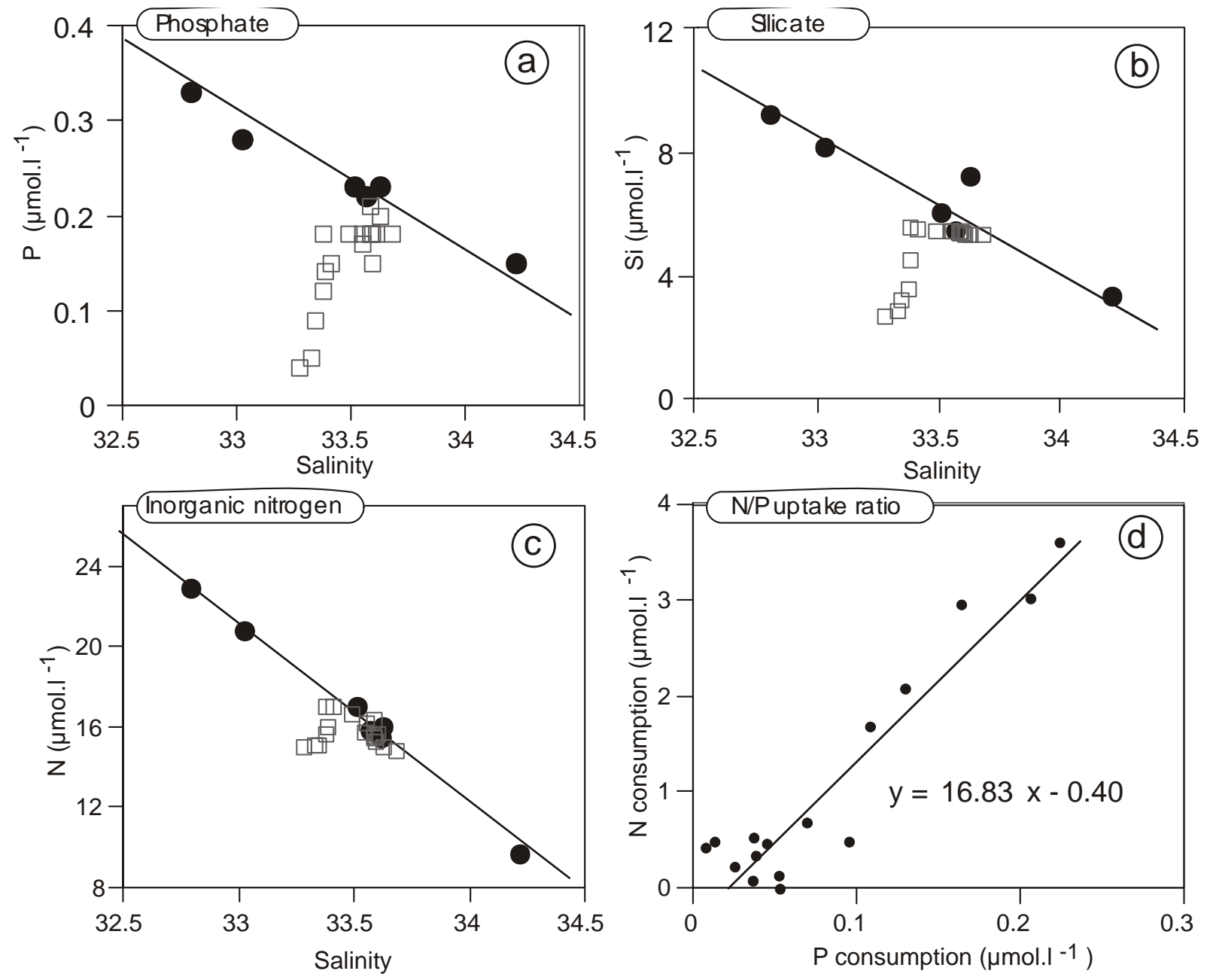

Figure 6: (a) Phosphate-salinity, (b) Silicate-salinity and (c) Nitrogen-salinity relationships at the station 30 (14 April 2002) - black circle $=$ concentrations in the Loire mouth; open square $=$ concentrations in the samples of the FSS. The regression line in graphs a, b and c is computed with the Loire mouth data and reflects conservative mixing concentrations which are used to determine nutrient uptake in the various layers (see text). (d) Relationship between $\mathrm{N}$ and $\mathrm{P}$ consumption giving the $\mathrm{N} / \mathrm{P}$ uptake ratio.

\subsubsection{Summer period}

Conversely to spring conditions, high thermal stratification characterized the water column at station 23 (Figure 4). The warmer upper layer was limited by the thermocline at around $12 \mathrm{~m}$. Salinity increased from 33.4 near the surface to 34.9 at $22 \mathrm{~m}$. Fluorescence was very low in the upper layer and sharply increased at $12 \mathrm{~m}$ with high variability in the sensor signal, reflecting heterogeneous distributions of fluorescent particles at this depth, as already identified with the PSA during the pelagic profiler cast. 
To describe the transition zone located around the thermocline, the 15 bottles of the FSS were simultaneously closed between 11 and $13.8 \mathrm{~m}$. Temperature values dropped from $17.8^{\circ} \mathrm{C}$ in the upper bottle to $13.2^{\circ} \mathrm{C}$ in the lower one, generating a sharp pycnocline. Light irradiance increased from 28 to $2200 \mu \mathrm{E} . \mathrm{m}^{-2} . \mathrm{s}^{-1}$ between $14 \mathrm{~m}$ and the surface.

Fine scale sampling within the water column allowed the detailed characterization of the vertical distribution of phytoplankton biomass and assemblage. Conversely to the spring period, the chlorophyll concentration in the upper layer was very low. There was an increase in the proportion of pheopigments just above the pycnocline, with a maximum at $11.2 \mathrm{~m}$ in relation to low chlorophyll $a$ values (Figure 7). This pattern can be attributed to the settling of large diatoms which were observed in low abundance in the upper water column (Thalassionema nitzschoides, Skeletonema costatum, Rhizosolenia delicatula).

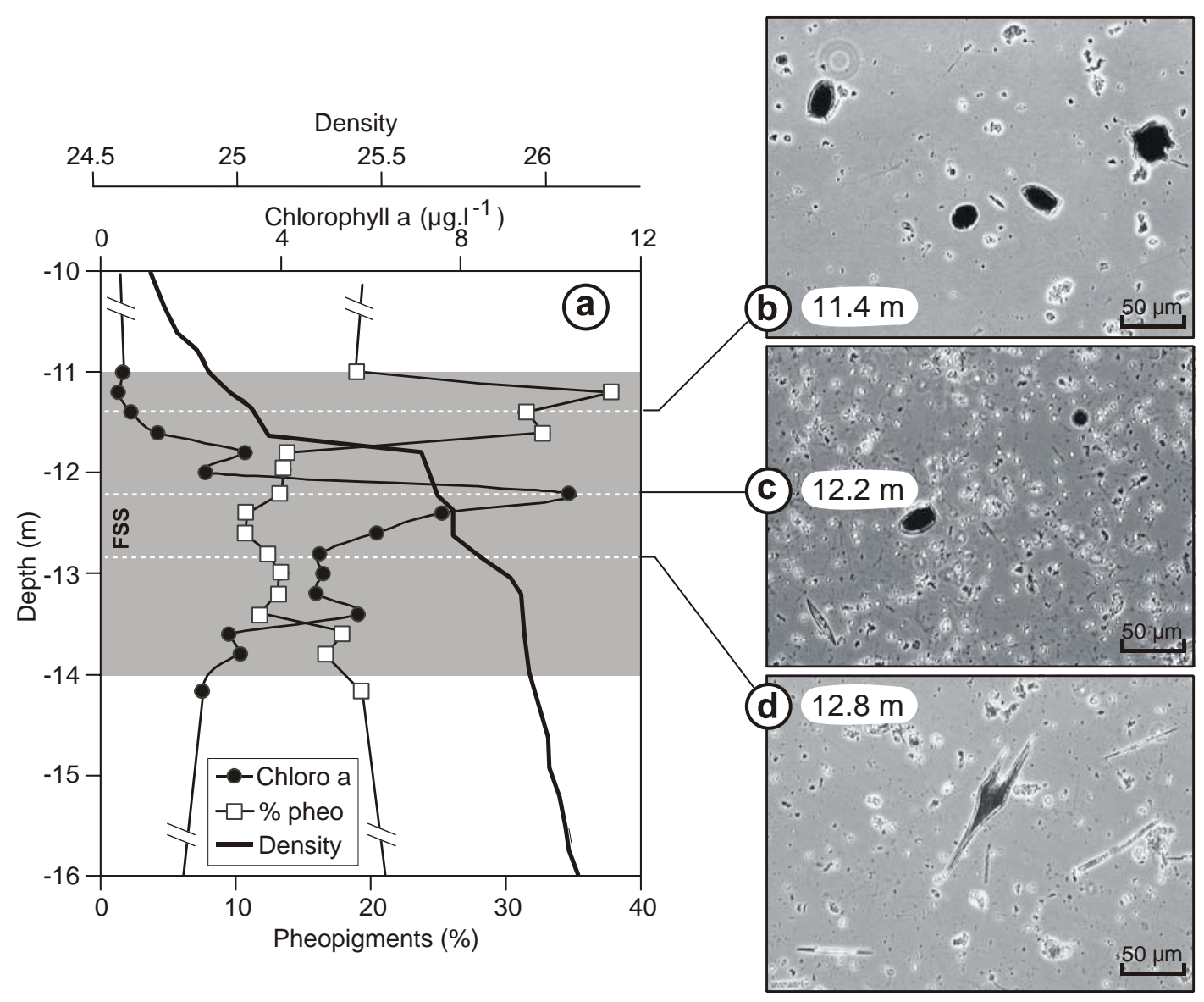

Figure 7: Vertical profiles of density, chlorophyll and pheopigments (a) around the pycnocline and examples of microscopic observations from samples taken around the phytoplankton peak (b, c, d). The thin layer was located below the pycnocline and was dominated by colonies of Chaetoceros sociale (c). The water above the pycnocline mostly contained individual diatoms and the maximum number of Dinophysis was observed in this layer (b). Detrital aggregates, senescent diatoms and dinoflagellates were observed below the maximum of chlorophyll $a(\mathrm{~d})$.

The chlorophyll $a$ concentration reached $10 \mu \mathrm{g} \mathrm{l}^{-1}$ just below the pycnocline (between 12 and $13 \mathrm{~m}$ ). In this thin layer, the maximum amount of phytoplankton was found at the bottom of the euphotic zone, where available light ranged from 1 to $3 \%$ of the surface irradiance. In this large phytoplankton biomass, colonies of Chaetoceros sociale (Figure 8) were predominant and contribute to $95-99 \%$ of total diatoms. In the upper layer, Chaetoceros sociale was less dominant (60-77\%) and it should be noted that Skeletonema costatum was found in a thin peak at $11.4 \mathrm{~m}$ and was not detected 
at all below 12 meters (Figure 8). Smallest forms of phytoplankton (Chrysophytes, Cryptophytes) were also more abundant in the upper layer. Dinoflagellates species including Dinophysis acuminata and Gymnodinium spp. were located and differently distributed within thin layers around the pycnocline. The concentrations of other dinoflagellates species (Prorocentrum micans, Ceratium furca, Gonyaulax diacantha) also increased within the density gradient, but their abundance with depth was randomly variable around the phytoplankton peak (data not shown).

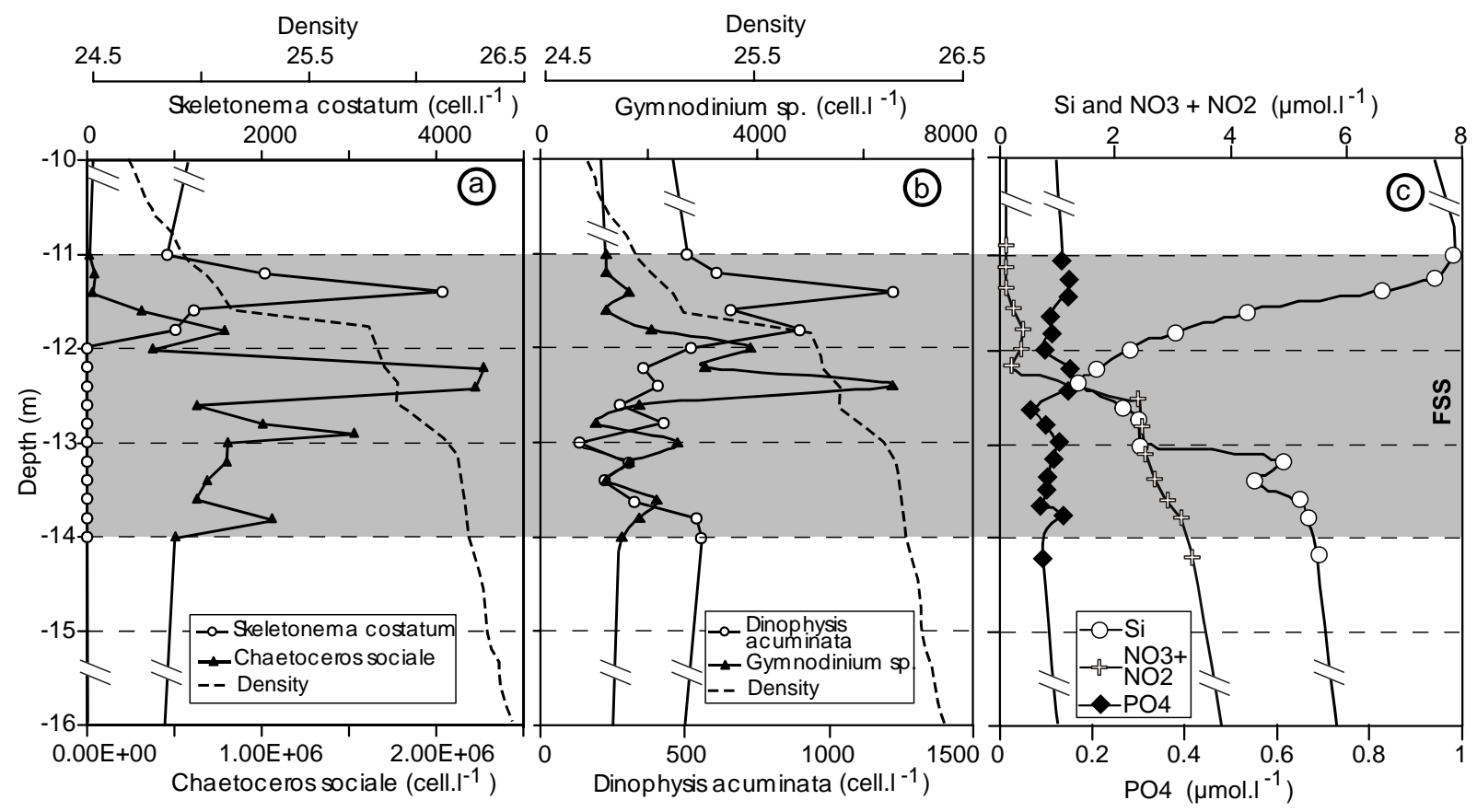

Figure 8: Vertical distribution of Skeletonema costatum and Chaetoceros sociale (a); Dinophysis acuminata and Gymnodinium spp. (b) and of silicate, inorganic nitrogen and phosphate (c) around the pycnocline at station 23 (21 June 2003).

Vertical distributions of dissolved inorganic nutrients in the pycnocline layer are shown in Figure 8. In this layer, the silicate distribution presented deep depletion suggesting a high uptake by the abundant diatoms. In the surface water column, silicate concentrations ranged from 7.7 to $3.7 \mu \mathrm{mol}^{-1} \mathrm{l}^{-1}$ and did not appear as a limiting nutrient for diatoms. Inorganic nitrogen exhibited high concentrations in the bottom water $\left(3.5-6.7 \mu \mathrm{mol}^{-1} \mathrm{l}^{-1}\right)$, and dropped in the pycnocline layer where phytoplankton biomass was maximum. Nitrogen concentration was very low within the whole upper layer (0.13-0.09 $\left.\mu \mathrm{mol}^{\mathrm{I}^{-1}}\right)$ indicating a limitation of phytoplankton growth by this element in the euphotic zone. However, non-negligible values of $\mathrm{NH}_{4}$ (ranging between 0.35 and $0.43 \mu \mathrm{mol}^{-1}{ }^{-1}$, graph not shown) were measured above $12 \mathrm{~m}$ indicating probable re-mineralization of organic nitrogen. Surprisingly the concentration of phosphate seemed to be unaffected by high phytoplankton biomass within the pycnocline layer. In the upper water column, phosphate concentrations ranged from $0.13 \mu \mathrm{mol}^{-l^{-1}}$ at $11 \mathrm{~m}$ to $0.03 \mu \mathrm{mol} . \mathrm{l}^{-1}$ near the surface, hence also reaching a concentration limiting phytoplankton growth.

\section{Discussion and conclusion}

\subsection{Fine Scale sampling technique}

Thanks to the high resolution sampling method used, some new information was acquired on phytoplankton production and diversity with respect to the vertical thermohaline structure and the 
distribution of dissolved inorganic nutrients. Relationships between sensors data and discrete sampling reveal a good accordance (graph not shown) for the salinity values (discrete salinity $=0.9633^{*}$ salinity sensor $+1.258, r^{2}=0.997$ ) and in a lesser extent for the chlorophyll values (Table 1). Discrete salinity values are particularly well related to sensors data suggesting a good reliability of the sampling technique. It should be noted that variations in dissolved properties are much smoother than particle distributions (phytoplankton biomass and size distribution). Such differences of patchiness between dissolved (physical and chemical properties) and biological parameters were also observed and described in tidally mixed coastal waters by Seuront et al. (2002). Consequently, thin layers of dissolved parameters are likely to be accurately measured by appropriate in situ techniques (Hanson and Donaghay, 1998; Johnson and Coletti, 2002). Vertical changes in phytoplankton species composition assemblages can also be in situ resolved by spectral absorption measurements (Eisner et al., 2003). However an accurate description of the phytoplankton assemblages and of its vertical layering can only be achieved through high resolution sampling techniques and microscopic examinations (Mouritsen and Richardson, 2003). Finally, it also appears that Fine Scale Sampling within strong vertical gradients is an appropriate method in order to accurately sample the physical, chemical and bio-optical profiles highlighted by in situ sensors.

\subsection{Phytoplankton biomass and nutrient limitation}

The two stations were located 20 miles westward off the Loire mouth, outside of the turbid river plume (Gohin, 2004), in a transition zone between coastal waters and open sea. This area is characterized by thermohaline stratifications and high phytoplankton productivity related to large dissolved nutrient inputs from the Loire River (Morin, 1991; Chapelle et al., 1994; Lampert et al., 2002). For both seasonal situations, the fine scale variability of phytoplankton assemblage was studied in relation to relevant hydrochemical parameters.

In spring, the surface layer was separated from bottom waters by a halocline located at nearly $16 \mathrm{~m}$ in depth. The upper layer of lower-salinity water exhibited a homogeneous phytoplankton biomass reaching $5 \mu \mathrm{g} \mathrm{l}^{-1}$ of chlorophyll $a$. The factors that limited phytoplankton growth at the boundaries of this productive layer (see arrows in Figure 9) were (i) the low light energy under $16 \mathrm{~m}$, and (ii) close to the surface, the low phosphate concentration which became limiting $\left(0.04 \mu \mathrm{mol}^{-1} \mathrm{l}^{-1} \mathrm{P}\right.$ $\mathrm{PO}_{4}$ ) at the top of the water column. In addition, it was also pointed out that a phytoplankton alkaline phosphatase activity is emerging in response to such low levels of phosphate (Labry et al., 2005). Inorganic nitrogen (Figure 9) and silicate (data not shown) were partly consumed but never reached limiting concentrations within the productive layer during spring conditions (Sarthou et al., 2005). These results are in agreement with previous studies of the continental shelf of the Bay of Biscay. They demonstrated that, in spring, a large phytoplankton biomass of large diatoms was found within the upper euphotic zone during nutrient-replete conditions (Herbland et al., 1998; Gohin et al., 2003). Similar halo-stratification with early diatom blooms was already observed during late winter in the Gironde plume, located in the southern part of the Bay of Biscay (Labry et al., 2001). The nutrient consumption observed in the surface layer in spring occurred with $\mathrm{N} / \mathrm{P}$ and $\mathrm{Si} / \mathrm{N}$ uptake ratios similar to usual Redfield values and corresponded to nutrient assimilation by diatoms. Neither inorganic nitrogen nor silicate appeared as a limiting nutrient in spring in the river plume. Possible limitation by phosphate can begin to take place within the euphotic layer of the river plume, as already noted by Labry et al. (2002). 

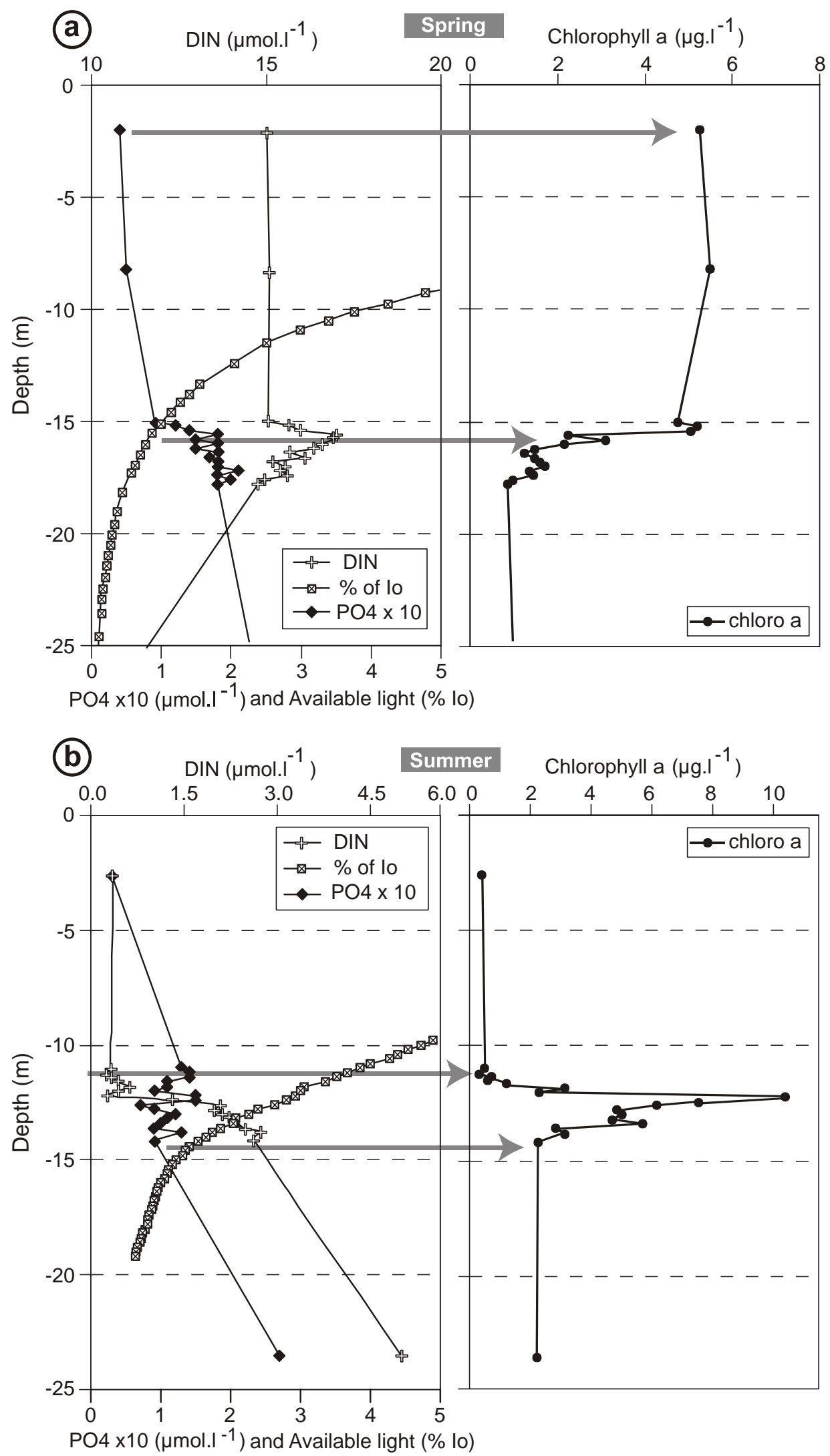

Figure 9: Vertical profiles of inorganic nitrogen (DIN), phosphate, available light, and chlorophyll $a$ under spring conditions (a); horizontal arrows indicate the limiting factors of phytoplankton growth (lower grey arrow $=$ light limitation; upper grey arrow $=$ probable phosphate limitation). Vertical profiles of inorganic nitrogen, phosphate, available light, and chlorophyll $a$ under summer conditions (b); horizontal arrow indicates the limiting factors for phytoplankton growth, lower arrow: light limitation - upper arrow: DIN limitation. 
Under summer conditions, a marked thermocline was located at $12 \mathrm{~m}$ in depth. At this level, a two meter thick layer was characterized by the presence of a high phytoplankton biomass, with chlorophyll $a$ concentrations reaching $10 \mu \mathrm{g} \mathrm{l}^{-1}$ (Figure 9). Logically, light is the limiting factor for phytoplankton growth at the lower boundary of this productive layer; in fact light irradiance reached a maximum value of $50 \mu \mathrm{E} \mathrm{m}^{-2} \mathrm{~s}^{-1}$ at this level during the summer cruise; this irradiance is a lower value than $E_{k}$ (light saturation parameter informing about light limitation) established by Labry et al. (2001) for diatoms in the Bay of Biscay ( $350 \mu \mathrm{E} \mathrm{m}^{-2} \mathrm{~s}^{-1}$ ) or by Sarthou et al. (2005) for diatom community $\left(95 \pm 40 \mu \mathrm{E} \mathrm{m}^{-2} \mathrm{~s}^{-1}\right)$. At the upper boundary, which was two meters above, the inorganic nitrogen fell to $0.4 \mu \mathrm{mol} . \mathrm{l}^{-1}$; this concentration could be a limiting level for diatom growth in the upper water column, considering the weak chlorophyll concentration and the observed nitrogen concentration far lower than half saturation constants (Cloern, 2001; Sanders et al., 2001; Sarthou et al., 2005). In similar summer conditions in this plume area, Chapelle et al. (1994) gave the proof with bioassay that nitrogen was the limiting nutrient for phytoplankton production. Silicate was not limiting in any situation and the lowest concentration encountered was $1.34 \mu \mathrm{mol}^{-1} \mathrm{I}^{-1}$ within the summer diatom peak. These results are in agreement with those of Ragueneau et al. (2002) in the North-western Black Sea and Del Amo et al. (1997) in the Bay of Brest; neither of whom found any silicate limitation in summer period. Both authors suggested that there could be an enrichment in dissolved silica in the bottom layer due to an intense re-dissolution of biogenic silica at the benthic interface. The same observation can be made for the phosphate which was always found at non-limiting concentration levels in the 15 samples bracketing the thin layer of chlorophyll $a$. It appeared that phosphate exhaustion could only be detected on the surface. This may be due to local phosphorus enrichment due to desorption of phosphate from particles or to bacterial decomposition of organic matter from aggregates observed around the pycnocline. Similar observations showing internal sources of phosphate in coastal areas have already been described (Yin et al., 2001).

In summer, it was also demonstrated that the phytoplankton peak was established within and below the pycnocline-nitracline, suggesting: (i) a low vertical dispersion of particles in this layer due to lower particle sedimentation rate and consequent temporary aggregation within the pycnocline, (ii) an enhanced growth condition due to irradiance and nutrient availability. Formation and persistence of thin layers in the ocean can result of various physical processes as near-inertial wave shear (Franks, 1995) or disintegration of a thicker layer into a thin layer associated to the horizontal intrusion of water masses (Osborn, 1998). Pycnocline (thermocline, halocline) can also decrease vertical mixing rates favoring the establishment of thin layers (Donaghay and Osborn, 1997). High biogeochemical activities (Hanson and Donaghay, 1998) have been quantified within those thin layers where are often located dense concentrations of phytoplankton (Sieracki et al., 1998; Rines et al., 2002).

Concerning the role of the zooplankton, estimations of ingestion rate and grazing impact of micro- and mesozooplankton on phytoplankton were made in spring (Sautour, pers. comm.) according to published methods (Sautour et al., 2000). These measurements revealed that within the mixed layer, the daily grazing pressure of microzooplankton on nano- and picophytoplancton was high (daily grazing pressure about $75 \%$ per day). On the contrary the mesozooplankton appeared to have a weak grazing pressure on microphytoplankton which constituted the prevailing highly productive biomass of microalgae in this nutrient replete plume area. In this way the zooplankton community seems not to have drastic impact on phytoplankton biomass within the mixed layer. Unfortunately no study of the zooplankton community was made during the summer cruise; nevertheless it was possible that above the pycnocline, the grazing pressure exerted by a well established zooplankton community was high, compared to a nutrient limited algal production. This was the pattern encountered by Sautour et al. (2000) in the South of the Bay of Biscay.

To summarize, from the two sets of observations, it appears that in the surface water of the river plume, during the spring-summer period, biological and chemical processes lead to a shift in nutrient limitation from $\mathrm{P}$ to $\mathrm{N}$ for phytoplankton growth. Similar observations were also presented by Labry et al. (2002) for the Gironde plume. 


\subsection{Distribution of Diatoms}

When comparing the two seasonal situations, it clearly appeared that the structure of the phytoplankton assemblage showed important changes in vertical distributions. They were mainly controlled by the density gradient and by the vertical distribution of the dissolved nutrients. For example, the FSS highlighted the high concentration of diatoms in a deep thin layer during summer, whereas the diatoms lay within the nutrient-replete photic zone during spring. The bloom was mainly dominated by large diatoms (Thalassiosira rotula, Chaetoceros sp....) under good nutrient conditions and no significant patchiness in diatom assemblage could be detected within the euphotic layer. Thalassiosira species are nutrient-sensitive (Waite et al., 1992) and need high nutrient concentration to sustain growth and compensate for their high settling rate. During spring, maintaining this diatom bloom leads to nutrient deficiency in the surface layer, resulting in the senescence and the sedimentation of the phytoplankton populations, as was observed during the summer cruise, where we found that Thalassosira has completely disappeared from the water column. High sedimentation rates for this species were already reported by Passow (1991) and Turner et al. (2002), when nitrogen was depleted.

In summer, under nutrient depleted conditions, the mechanisms controlling the growth, the maintenance and the accumulation of species in precise layers are complex and difficult to determine. This investigation requires studying the environmental factors ( $T, S$, nutrients, light, and turbidity) in relation to the ecophysiology and the morphology of the taxa. In our state of knowledge we have no evidence which could precisely explain the fine depth layering of phytoplankton assemblages that we observed. In particular, this would have required the acquisition of fluxes of nutrients. However, two hypotheses can explain the patchy abundance of Skeletonema costatum observed at $11 \mathrm{~m}$ : (i) $\mathrm{NH}_{4}$ values around $11 \mathrm{~m}$ are relatively high $\left(0.4 \mu \mathrm{mol} \mathrm{l}^{-1}\right)$, probably due to the high abundance and remineralization of particles at this level. Under $\mathrm{NO}_{3}+\mathrm{NO}_{2}$ depleted condition, this $\mathrm{NH}_{4}$ could be the main source of nitrogen for $S$. costatum; (ii) averaged light adaptation parameter for $S$. costatum was determined to $46 \mu \mathrm{E} . \mathrm{m}^{2} . \mathrm{s}^{-1}$ (Langdon, 1988), this reference value indicates that in summer conditions this species was irradiance limited below $12 \mathrm{~m}$. With respect to the physiochemical characteristics of the water column, our data suggest that $S$. costatum found best growth conditions between 10 and 12 meters due to its specific nitrogen and light metabolisms.

Below 12 meter, it was determined that some colonies of Chaetoceros formed abundant large-sized colonies. In some cases, fresh and senescent colonies of Chaetoceros sociale can contribute to marine snow (Sieracki et al., 1998; Turner, 2002; Gallager et al., 2004). The slow settling of Chaetoceros cells may be due to their long "hair-like spines", which increase friction and lower sinking rates (Smayda and Boleyn, 1966). Mechanisms of formation, maintenance and dissipation of thin layers of particles in coastal areas have often been discussed. Particles and phytoplankton can accumulate at density discontinuities, at the base of the mixed layer and below the pycnocline through a reduction in sinking velocity as they enter a region of greater density and viscosity (MacIntyre et al., 1995). Moreover, sinking rates of marine diatoms vary widely within density gradients depending on their physiological state and on nutrient conditions (Bienfang et al., 1982; Passow, 1991).

\subsection{Distribution of Dinoflagellates}

This study may also suggest that the largest significant differences found in the distribution pattern of species come from their ability to control their vertical position in the water column. In comparison to diatoms which can only regulate their depth by buoyancy, dinoflagellates can actively migrate (as an example, Karenia mikimotoï can vertically migrate at $+-10 \mathrm{~m} \mathrm{~d}^{-1}$, (Gentien, 1998)). The swimming behavior of flagellates is mainly influenced by photosynthetic activity and nutrition. (MacIntyre et al, 1997; Olli, 1999). Using a High Resolution Sampler, Bjornsen and Nielsen (1991) have found that high densities of dinoflagellates were associated with a decreased abundance of microzooplankton. In spring conditions, this could explain the presence of the peak of small dinoflagellates found exactly under the pycnocline with low abundance of diatoms and low values of incident irradiance. At the entrance to the Gulf of Finland, Kononen at al. (2003) had shown the 
development of a deep 30-35 m chlorophyll maximum with predominance of Heterocapsa triquetra, under dark conditions. The authors demonstrated that $H$. triquetra population migrated from the nitrate depleted euphotic zone down to the top of the nitracline at 30-35 m.

Specific biochemical processes can also explain the increase in some phytoplankton species within the pycnocline. Le Corre and L'Helguen (1993) showed that the decomposition of senescent diatoms constituted internal sources of available nutrients, like ammonium, for dinoflagellate growth around and above the pycnocline. This could explain the formation of the Dinophysis acuminata patch found in summer around $11 \mathrm{~m}$, where there was an accumulation of detritus material accurately resolved by the diffraction method which is very sensitive to the abundance of loose aggregates and organic particles (Lunven and Gentien, 2000). The abundance of small forms of microplankton (Chlorophytes and Cryptophytes) found at this level also suggests that Dinophysis could feed upon these small species as already demonstrated in previous studies (Hansen, 1991; Jacobson and Andersen, 1994).

However, these thin layers of mobile species can be mixed and eroded under high turbulence conditions (Lohrenz et al., 2003). On the basis of results obtained with a High Resolution Sampler, Maar et al. (2003) suggested that the patchiness of swimmers (ciliates, flagellates) can decrease dramatically as turbulent diffusion levels increase. Depending on physical conditions such as windinduced turbulent mixing, thin layers of phytoplankton may also be transported from the pycnocline to frontal areas and appear as a surface bloom (Tyler, 1984).

To conclude, it appears that simultaneous sampling provided by the 15 bottles of the FSS allows a non-biased characterization of the stratified waters with regard to hydrologic parameters along with phytoplankton biomass and assemblage within the sampled layers. This method is important for coastal areas where high resolution observations are needed to improve knowledge about the process controlling primary production in the river plumes and the local vertical variability of phytoplankton species.

\section{Acknowledgements}

Development of the FSS and field studies are contributions to the "Golfe de Gascogne" (Bay of Biscay) program funded by Ifremer (France). We especially thank the captain and crew of $\mathrm{R} / \mathrm{V}$ Thalassa and R/V Côtes de la Munches for their assistance in deploying the field instrumentation. The authors would also like to thank the three anonymous reviewers for their corrections and recommendations in improving the manuscript.

\section{References}

Alldredge, A.L., Cowles, T.J., MacIntyre, S., Rines, J.E.B., Donaghay, P.L., Greenlaw, C.F., Holliday D.V., Dekshenieks, M.M., Sullivan, J.M., Zaneveld, J.R.V., 2002. Occurrence and mechanisms of formation of a dramatic thin layer of marine snow in a shallow Pacific fjord. Marine Ecology Progress Series 233, 1-12.

Benfield, M.C., Davis, C.S., Wiebe, P.H., Gallager, S.M., Lough, R.G., Copley, N.J., 1996. Video Plankton Recorder estimates of copepod, pteropod and larvacean distributions from a stratified region of Georges Bank with comparative measurements from a MOCNESS sampler. Deep Sea Research 43, 1925-1945.

Bjørnsen, P.K., Nielsen, T.G., 1991. Decimeter scale heterogeneity in the plankton during a pycnocline bloom of Gyrodinium aureolum. Marine Ecology Progress Series 73, 263-267. 
Bienfang, P.K., Harrisson, P.J., Quarmby, L.M., 1982. Sinking rate response to depletion of nitrate, phosphate and silicate in four marine diatoms. Marine Biology 67, 295-302.

Brzezinski, M.A., 1985. The Si-C-N ratio of marine diatoms inter-specific variability and the effect of some environmental variables. Journal of Phycology 21, 347-357.

Chapelle, A., Lazure, P., Ménesguen, A., 1994. Modelling eutrophication events in a coastal ecosystem. Sensitivity analysis. Estuarine Coastal and Shelf Science 39, 529-548.

Cloern, J.E., 2001. Our evolving conceptual model of the coastal eutrophication problem. Marine Ecology Progress Series 210, 223-253.

Cowles, T.J., Desiderio, R.A., 1993. Resolution of biological micro-structure through in situ fluorescence emission spectra. Oceanography 6, 105-111.

Dekshenieks, M.M., Donaghay, P.L., Sullivan, J.M., Rines, J.E.B., Osborn, T.R., Twardowski, M.S., 2001. Temporal and spatial occurrence of thin phytoplankton layers in relation to physical processes. Marine Ecology Progress Series 223, 61-71.

Del-Amo, Y., Queguiner, B., Treguer, P., Breton, H., Lampert, L., 1997. Impacts of high-nitrate freshwater inputs on macrotidal ecosystems. 2. Specific role of the silicic acid pump in the year-round dominance of diatoms in the Bay of Brest (France). Marine Ecology Progress Series 161, 225-237.

Donaghay, P.L., Rines, H.M., McNeil Sieburth, J., 1992. Simultaneous sampling of fine scale biological, chemical and physical structure in stratified waters. Ach. Hydrobiol. Beih. 36, 97-108.

Donaghay, P.L., Osborn, T.R., 1997. Toward a theory of biological-physical control of harmful algal bloom dynamics and impacts. Limnology and Oceanography 42, 1283-1296.

Dortch, Q., Whitledge, T.E., 1992. Does nitrogen or silicon limit phytoplankton production in the Mississipi River plume and nearby region? Continental Shelf Research 12, 1293-1309.

Eisner, L.B., Twardowski, M.S., Cowles, T.J., 2003. Resolving phytoplankton photoprotective: photosynthetic carotenoid ratios on fine scales using in situ spectral absorption measurements. Limnology and Oceanography 48, 632-646.

Flynn, K.J., Martin-Jézéquel, V., 2000. Modelling Si-N-limited growth of diatoms. Journal of Plankton Research 22, 447-472.

Francks, P.J.S., 1995. Thin layers of phytoplankton: a model of formation by near-inertial wave shear. Deep Sea research 42, 75-91.

Gallager, S.M., Yamazaki, H., Davies, C.S., 2004. Contribution of fine-scale vertical structure and swimming behavior to formation of plankton layers on Georges Bank. Marine Ecology Progress Series 267, 27-43.

Gentien, P., Lunven, M., Le Haitre, M., Duvent, J.L., 1995. In situ depth profiling of particle sizes. Deep Sea Research 42, 1297-1312.

Gentien, P., 1998. Bloom dynamics and Ecophysiology of Gymnodinium mikimotoï Species Complex. Physiological Ecology of Harmful Algal Blooms in Anderson, D.M., Cembella, A.D., Hallegraeff G.M. eds, p. 155-173. 
Gohin, F., Lampert, L., Guillaud, J.F., Herbland, A., Nézan, E., 2003. Satellite and in situ observations of a late winter phytoplankton bloom, in the northern Bay of Biscay. Continental Shelf Research 23, 1117-1141.

Gohin, F., Loyer, S., Lunven, M., Labry, C., Froidefond, J.M., Delmas, D., Huret, M., Herbland, A., 2005. Satellite derived parameters for biological modeling in coastal waters: Illustration over the northern continental shelf of the Bay of Biscay. International Journal of Remote Sensing 95, 29-46.

Grasshoff, K., Ehrhardt, M., Kremling, F., 1983. Methods of seawater analysis (2 ${ }^{\text {nd }}$ ed), Verlag Chemie, Weinheim, 410 pp.

Hansen, P.J., 1991. Dinophysis - a planktonic dinoflagellates that can act both as a prey and a predator of a ciliate. Marine Ecology Progress Series 69, 201-204.

Hanson, A.K., Donaghay, P.L., 1998. Micro to fine-scale chemical gradients and layers in stratified coastal waters. Oceanography 11, 10-17.

Herbland, A., Delmas, D., Laborde, P., Sautour, B., Artigas, F., 1998. Phytoplankton spring bloom of the Gironde plume waters in the Bay of Biscay: early phosphorus limitation and food-web consequences. Oceanologica Acta 21, 279-291.

Jacobson, D.M., Andersen, R.A., 1994. The discovery of mixotrophy in photosynthetic species of Dinophysis (Dinophyceae): light and electron microscopical observations of food vacuole in Dinophysis acuminate, D. norvegica and two heterotrophic dinophysoid dinoflagellates. Phycologia 33, 97-110.

Johnson, K.S., Coletti, L.J., 2002. In situ ultraviolet spectrophotometry for high resolution and long term monitoring of nitrate, bromide and bisulfide in the ocean. Deep Sea Research 49, 1291-1305.

Kérouel, R., Aminot, A., 1997. Fluorimetric determination of ammonia in sea and estuarine waters by direct segmented flow analysis. Marine Chemistry 57, 265-275.

Kononen, K., Huttunen, M., Hällfors, S., Gentien, P., Lunven, M., Huttula, T., Laanemets, J., Lilover, M., Pavelson, J., Stips, A., 2003. Development of a deep chlorophyll maximum of Heterocapsa triquetra Ehrenb. at the entrance to the Gulf of Finland. Limnology and Oceanography 48, 594-607.

Labry, C., Herbland, A., Delmas, D., Laborde, P., Lazure, P., Froidefond, J.M., Jegou, A.M., Sautour, B., 2001, Initiation of winter phytoplankton blooms within the Gironde plume waters in the Bay of Biscay. Marine Ecology Progress Series 212, 117-130.

Labry, C., Herbland, A., Delmas, D., 2002. The role of phosphorus on planktonic production of the Gironde plume waters in the Bay of Biscay. Journal of Plankton Research 24, 97-117.

Labry, C., Herbland, A., Delmas, D., 2005. Phytoplankton and bacterial alkaline phosphatase activities in relation to phosphate and DOP availability within the Gironde plume waters (Bay of Biscay). Journal of Experimental Marine Biology and Ecology 318, 213-225.

Langdon, C., 1988. On the cause of interspecific differences in the growth irradiance relationship for phytoplankton. Part 1. A comparative study of the growth-irradiance relationship of three marine phytoplankton species: Skeletonema costatum, Olisthodiscus luteus and Gonyaulax tamarensis. Journal of Plankton Research 9, 459-482.

Lampert, L., Quéguiner, B., Labasque, T., Pichon, A., Lebreton, N., 2002. Spatial variability of phytoplankton composition and biomass on the eastern continental shelf of the Bay of Biscay (north- 
east Atlantic Ocean). Evidence for a bloom of Emiliana huxleyi (Prymnesiophyceae) in spring 1998. Continental Shelf Research 22, 1225-1247.

Le Corre, P., L’Helguen, S., 1993. Nitrogen source for uptake by Gyrodinium aureolum in a tidal front. Limnology and Oceanography 38, 446-451.

Lohrenz, S.E., Carroll, C.L., Weidemann, A.D., Tuel, M., 2003. Variations in phytoplankton pigments, size structure and community composition related to wind forcing and water mass properties on the North Carolina inner shelf. Continental Shelf Research 23, 1447-1464.

Lunven, M., Gentien, P., 2000. Suspended sediment in a macrotidal estuary: comparison and use of different sensors. Oceanologica Acta, 23, 245-259.

Lunven, M., Gentien, P., Kononen, K., Le Gall, E., Daniélou, M.M., 2003. In situ video and diffraction analysis of marine particles. Estuarine Coastal and Shelf Science 57 , 1127-1137.

MacIntyre, J.G., Cullen, J.J., Cembella A.D., 1997. Vertical migration, nutrition and toxicity in the dinoflagellate Alexandrium tamarense. Marine Ecology Progress Series 148, 201-216.

Maar, M., Nielsen, T.G., Stips, A., Visser, A.W., 2003. Microscale distribution of zooplankton in relation to turbulent diffusion. Limnology and Oceanography 48, 1312-1325.

Mackas, D.L., Denman, K.L., Abbott, M.R., 1985. Plankton patchiness: biology in the physical vernacular. Bulletin of Marine Science 37, 652-674.

MacIntyre, S., Alldredge, A.L., Gotschalk, C.C., 1995. Accumulation of marine snow at density discontinuities in the water column. Limnology and Oceanography 40 , 449-468.

Morin, P., Le Corre, P., Marty, Y., L’Helguen, S., 1991. Evolution printanière des éléments nutritifs et du phytoplancton sur le plateau continental armoricain (Europe du Nord Ouest). Oceanologica Acta $14,263-279$.

Mouritsen, L.T., Richardson, K., 2003. Vertical microscale patchiness in nano and microplankton distributions in a stratified estuary. Journal of Plankton Research 25 , 783-797.

Olli, K., 1999. Diel vertical migration of phytoplankton and heterotrophic flagellates in the Gulf of Riga. Journal of Marine Systems 23, 145-163.

Osborn, T.R., 1998. Finestructure, microstructure and thin layers. Oceanography 11, 36-43.

Owen, R.W., 1989. Microscale and fine scale variations of small plankton in coastal and pelagic environments. Journal of Marine Research 47, 197-240.

Passow, U., 1991. Species-specific sedimentation and sinking velocities diatoms. Marine Biology 108, 449-455.

Ragueneau, O., Lancelot, C., Egorov, V., Vervlimmeren, J., Cociasu, A., Déliat, G., Krastev, A., Daoud, N., Rousseau, V., Popovitchev, V., 2002. Biogeochemical Transformations of Inorganic Nutrients in the Mixing Zone between the Danube River and the North-western Black Sea. Estuarine Coastal and Shelf Science 54, 321-336.

Redfield, A.C., Ketchum, B.H., Richard, F.A., 1963. The influence of organisms on the composition of seawater. The Sea (Hill M. N. ed.). Wiley, New York, 26-77. 
Rines, J.E.B., Donaghay, P.L., Dekshenieks, M.M., Sullivan, J.M., Twardowski, M.S., 2002. Thin layers and camouflage: hidden Pseudo-nitzschia spp. (Bacillariophyceae) populations in a fjord in the San Juan Islands, Washington, USA. Marine Ecology Progress Series 225, 123-137.

Sanders, R., Jickells, T., Mills, D., 2001. Nutrients and chlorophyll at two sites in the Thames plume and southern North sea. Journal of Sea Research 46, 13-28.

Sarthou, G., Klass, R.T., Blain, S., Treguer, P., 2005. Growth physiology and fate of diatoms in the ocean: a review. Journal of Sea Research 53, 25-42.

Sautour, B., Artigas, L.P., Delmas, D., Herbland, A., Laborde, P., 2000. Grazing impact of micro- and mesozooplankton during a spring situation in coastal waters off the Gironde estuary. Journal of Plankton Research 22, 531-552.

Seuront, L., Gentilhomme, V., Lagadeuc, Y., 2002. Small-scale nutrient patches in tidally mixed coastal waters. Marine Ecology Progress Series 232, 29-44.

Sieraki, M.E., Gifford, D.J., Gallager, S.M., Davis, C.S., 1998. Ecology of Chaetoceros socialis lauder patch on Georges Bank: distribution, microbial associations and grazing losses. Oceanography 11, 3035.

Smayda, T.J., Boleyn, B.J., 1966. Experimental observations on the flotation of marine diatoms. III. Bacteriastrum hyalinium and Chaetoceros lauderi. Limnology and Oceanography 11, 35-43.

Strickland, J.D.H., Parsons, T.R., 1972. A practical handbook of seawater analysis. Bull. Fish. Res. Bd Can., 167, 311 pp.

Turner, J.T., 2002. Zooplankton fecal pellets, marine snow and sinking phytoplankton blooms. Aquatic Microbial Ecology 27, 57-102.

Tyler, M.A., 1984. Dye tracing of a subsurface chlorophyll maximum of a red-tide dinoflagellate to surface frontal regions. Marine Biology 78, 285-300.

Waite, A., Bienfang, P.K., Harrisson P.J., 1992. Spring bloom sedimentation in a subarctic ecosystem.I. Nutrient sensitivity. Marine Biology 114, 131-138.

Yin, K., Qian, P.Y., Wu, M., Chen, J., Huang, L., Song, X., Jian, W., 2001. Shift from P to N limitation of phytoplankton growth across the Pearl River estuarine plume during summer. Marine Ecology Progress Series 221, 17-28.

Yu, X., Dickey, T., Bellingham, J., Manov, D., Streitlien, K., 2002. The application of autonomous underwater vehicles for interdisciplinary measurements in Massachussetts and Cape Cod Bays. Continental Shelf Research 22, 2225-2245. 